\title{
New combinations in the treatment of COPD: rationale for aclidinium-formoterol
}

\author{
This article was published in the following Dove Press journal: \\ Therapeutics and Clinical Risk Management \\ 15 February 2016 \\ Number of times this article has been viewed
}

\section{Cristoforo Incorvaia' \\ Marcello Montagni² \\ Elena Makri \\ Erminia Ridolo² \\ 'Allergy/Pulmonary Rehabilitation, Istituti Clinici di Perfezionamento Hospital, Milan, ${ }^{2}$ Department of Clinical and Experimental Medicine, University of Parma, Parma, Italy}

\begin{abstract}
The current guidelines on chronic obstructive pulmonary disease (COPD) recommend the prominent use of bronchodilators, including long-acting $\beta_{2}$-agonists (LABAs) and longacting muscarinic antagonists (LAMAs), while inhaled corticosteroids are recommended only in patients with severe disease or frequent exacerbations. LABA-LAMA combinations are indicated when single bronchodilators are insufficient to control COPD. A number of LABA-LAMA combinations are available, based on twice-daily or once-daily administration according to the 12- or 24-hour duration of action, respectively. The aclidinium-formoterol combination is based on the new LAMA aclidinium bromide, which has a high selectivity for $\mathrm{M}_{3}$ muscarinic receptors and a fast onset of action, and the well-known LABA formoterol. Both drugs require twice-daily administration. The fixed-dose combination of aclidinium $400 \mu \mathrm{g} /$ formoterol $12 \mu \mathrm{g}$ has shown in randomized controlled trials fast and sustained bronchodilation that was greater than either monotherapy and provided clinically significant improvements in dyspnea and health status compared with placebo, also reducing the use of rescue medications. The overall incidence of adverse events was low and comparable to placebo. These data define the aclidinium-formoterol fixed-dose combination as a new treatment option for patients with COPD. The need for twice-daily administration could be an apparent disadvantage compared to the available once-daily LABA-LAMA combinations, but the immediately perceived benefit in reducing dyspnea due to the fast onset of action, as well as reported correct patient use and satisfaction with the Genuair inhaler might prove useful in favoring adherence.
\end{abstract}

Keywords: bronchodilators, COPD, LABA, LAMA, combination, efficacy, safety, inhalation device

\section{Introduction}

The pharmacological treatment of chronic obstructive pulmonary disease (COPD) is at present mainly based on bronchodilators, with inhaled corticosteroids (ICS) to be used only in patients with severe disease or frequent exacerbations. ${ }^{1,2}$ Inhaled bronchodilators belong to the two classes of $\beta_{2}$-agonists and muscarinic antagonists. The introduction of agents with long duration of action, namely the long-acting $\beta_{2}$-agonists (LABAs) and the long-acting muscarinic antagonists (LAMAs), was a landmark in their evolution. ${ }^{3,4}$ These drugs offered clear advantages in terms of patient adherence, being possible to inhale twice daily or once daily (according to a duration of 12 or 24 years) in place of the several inhalations each day required with short-acting $\beta_{2}$-agonists and muscarinic antagonists. In the last few years, the array of LABAs and LAMAs has expanded, adding to the first drugs (salmeterol and formoterol as LABAs and tiotropium as a LAMA) several other agents. These include indacaterol, olodaterol, vilanterol as a LABA, and glycopyrronium, aclidinium, and umeclidinium as LAMAs. ${ }^{5-8}$ Also, LABA-LAMA combinations were introduced that make it easier to take the drugs
Correspondence: Cristoforo Incorvaia Allergy/Pulmonary Rehabilitation, Istituti Clinici di Perfezionamento Hospital, I Via Bignami, Milan 20100, Italy

Tel +39025799 3289

Fax +39025799 3579

Email cristoforo.incorvaia@gmail.com
Therapeutics and Clinical Risk Management 2016:12 209-215

Dovepress

http://dx.doi.org/10.2147/TCRM.S82034 (c) (1) \& () 2016 Incorvaia et al. This work is published and licensed by Dove Medical Press Limited. The full terms of this license are available at https://www.dovepress.com/terms.php c. hereby accept the Terms. Non-commercial uses of the work are permitted without any further permission from Dove Medical Press Limited, provided the work is properly attributed. For permission for commercial use of this work, please see paragraphs 4.2 and 5 of our Terms (https://www.dovepress.com/terms.php). 
when double bronchodilation is required in patients insufficiently controlled by a single bronchodilator. ${ }^{2}$ As of now, the combinations authorized from regulatory agencies are indacaterol-glycopyrronium, umeclidinium-vilanterol, olodaterol-tiotropium, and formoterol-aclidinium. ${ }^{8}$ Here, we review the efficacy and safety of formoterol-aclidinium, first appraising the performances of the single components and then of their combination.

\section{Overview of pharmacology, mode of action, and pharmacokinetics of aclidinium and formoterol and rationale for fixed combination}

Formoterol was introduced in the 1980s as a bronchodilator for the treatment of asthma and COPD. Its characteristics can be summarized in a significant bronchodilator effect through $\beta_{2}$-selective adrenoceptor agonism, occurring within minutes of inhalation and persisting for approximately 12 hours, with no significant development of tachyphylaxis at therapeutic doses. ${ }^{9}$ With regard to efficacy, inhaled formoterol was shown to be equivalent to or better than comparable dosages of the conventional $\beta_{2}$-agonists salbutamol, fenoterol, and terbutaline. ${ }^{9}$ The prolonged duration of action of formoterol allowed for the first time (shortly followed by salmeterol) ${ }^{10}$ a twice-daily dosage regimen, resulting in improved control of nocturnal symptoms by reducing the "morning dip". 9 Derom et al recently evaluated the lung deposition (that assesses the pulmonary bioavailability of the drug) of different doses of inhaled formoterol via the dry-powder inhaler Turbuhaler $^{\circledR}$ in patients with COPD. The mean pulmonary bioavailability was approximately $24 \%$ of the nominal delivered dose, with no correlation between lung deposition and baseline value of forced expiratory volume in 1 second $\left(\mathrm{FEV}_{1}\right)$. All formoterol doses significantly increased $\mathrm{FEV}_{1}$ compared with placebo, while only the higher doses (18 and $36 \mu \mathrm{g})$ significantly decreased static lung volumes, such as functional residual capacity and residual volume. ${ }^{11}$

Aclidinium bromide, which is a LAMA with high selectivity for $\mathrm{M}_{3}$ muscarinic receptors and a fast onset of action, was recently introduced. In preclinical evaluation, aclidinium was compared to tiotropium concerning affinity toward different human muscarinic receptor subtypes, potency in inhibiting the agonist-induced activation of muscarinic receptors, and efficacy and duration of bronchoprotection in experimental models. Aclidinium showed affinity and potency comparable to tiotropium, while the dissociation half-life was 27 hours for tiotropium and 10.7 hours for aclidinium, this requiring twice-daily administration. ${ }^{12}$ The pharmacokinetics of aclidinium were evaluated in healthy subjects, who were randomized to receive five single increasing doses from 600 to 6,000 $\mu \mathrm{g}$ or placebo inhaled via dry-powder inhaler, with 7-day washouts. Aclidinium was rapidly converted in plasma into alcohol and carboxylic acid metabolites, and was no longer detectable after 3 hours postdose for all doses. Maximum plasma concentrations were reached within 5-7 minutes for all doses and declined rapidly. Mean elimination half-lives of aclidinium $>2,400 \mu \mathrm{g}$ were approximately 1 hour. ${ }^{13}$ Also, the lung deposition after administration by the dry-powder inhaler Genuair ${ }^{\circledR}$ was investigated. A single dose of $200 \mu \mathrm{g}$ of aclidinium, radiolabeled with ${ }^{99 \mathrm{~m}} \mathrm{Tc}$, was administered at a targeted peak inspiratory flow rate of $90 \mathrm{~L} / \mathrm{min}$ in 12 healthy males (18-63 years old), quantifying drug deposition in the lungs and oropharynx, as well as amounts retained in the inhaler. The mean peak inspiratory flow rate was 79.0 $\pm 9.4 \mathrm{~L} / \mathrm{min}$, and the mean percentages of the metered dose deposited in the whole lung and oropharynx were $30.1 \% \pm 7.3 \%$ and $54.7 \% \pm 7.2 \%$, respectively. Deposition of aclidinium occurred in all six lung zones, but was highest in the most central zone. ${ }^{14}$ A double-blind, partial crossover study on subjects treated with single doses of aclidinium $(50,300$, or $600 \mu \mathrm{g})$ or placebo assessed the drug activity on specific airway conductance $\left(\mathrm{sG}_{\mathrm{aw}}\right)$ and airway resistance $\left(\mathrm{R}_{\mathrm{aw}}\right)$. Aclidinium significantly increased $\mathrm{sG}_{\mathrm{aw}}$ compared with placebo at all assessments and doses, except $50 \mu \mathrm{g}$ at 1 and 24 hours. Significant decreases in $\mathrm{R}_{\mathrm{aw}}$ were observed with aclidinium 300 and $600 \mu \mathrm{g}$ compared with placebo at all assessments. For all end points, there was a significant difference between aclidinium $50 \mu \mathrm{g}$ and the higher doses $(P<0.0001)$. Aclidinium was not detected in plasma. ${ }^{15}$

The rationale for a fixed combination of aclidinium and formoterol in therapy for COPD is based on the similar onset and duration of action of these drugs and the superior effect of the combination compared with either drug alone. ${ }^{16}$

\section{Efficacy studies on the fixed combination of aclidinium- formoterol}

The most reliable method to establish the efficacy and safety of drug treatment is the systematic review and meta-analysis. The first Cochrane meta-analysis on formoterol concerned its efficacy as medication for asthma, based on eight studies with 22,604 participants. The authors concluded there was efficacy as a reliever similar to short-acting $\beta_{2}$-agonists and an ability to reduce the number of exacerbations requiring a course of oral CS, but with no evidence to recommend changes to 
guidelines that suggest that LABAs should be given only to patients already taking ICS. ${ }^{17}$ In fact, differently from COPD, the Global Initiative on Asthma guidelines recommend ICS as first-line treatment. ${ }^{18}$ In a Cochrane meta-analysis including both formoterol and salmeterol, 26 randomized controlled trials on a global number of 14,939 COPD patients with mean $\mathrm{FEV}_{1}$ between $33 \%$ and $55 \%$ of predicted normal were considered. ${ }^{19}$ The two LABAs improved predose FEV 1 by $73 \mathrm{~mL}$ more than placebo, improved quality of life, and reduced the number of exacerbations requiring hospitalization. The number of people who had exacerbations requiring a course of oral steroids or antibiotics was also lower among those taking LABAs. Moderate-quality evidence from the 26 studies showed that inhaled LABAs are effective over the medium and long term for patients with moderate-to-severe COPD. ${ }^{19}$

Despite aclidinium's recent introduction, a Cochrane systematic review is also available for the drug, based on 12 randomized controlled trials with an overall number of 9,547 patients with stable COPD. All but one study included in the meta-analysis were double-blind and scored low on risk of bias. Study durations ranged from 4 to 52 weeks. Participants were prevalently males, with a mean age ranging from 61.7 to 65.6 years, and had moderate-to-severe symptoms at randomization; mean postbronchodilator $\mathrm{FEV}_{1}$ was between $46 \%$ and $57.6 \%$ of the predicted normal value. The results of the analysis showed that aclidinium gave significantly greater improvement in predose $\mathrm{FEV}_{1}$ than placebo and improved quality of life by lowering the St George's Respiratory Questionnaire (SGRQ) total score, with a mean difference of -2.34 when compared to placebo. Also, aclidinium reduced the number of patients with exacerbations requiring hospitalization. There was no difference in nonfatal serious adverse events between aclidinium and placebo. Compared to tiotropium, aclidinium did not demonstrate significant differences for exacerbations requiring oral steroids or antibiotics, or both, or exacerbation-related hospitalizations. ${ }^{20}$

Due to the recent introduction of the aclidinium-formoterol combination, no meta-analysis on it is available, but large scale controlled trials were performed. In the ACLIFORMCOPD trial, 1,344 patients aged more than 40 years with postbronchodilator $\mathrm{FEV}_{1}$ /forced vital capacity $<70 \%$ and $\mathrm{FEV}_{1}$ between $30 \%$ and $80 \%$ of predicted normal were randomized to aclidinium-formoterol via the Genuair/ Pressair ${ }^{\circledR}$ inhaler in a 24-week, double-blind, parallel-group, active- and placebo-controlled, multicenter Phase III study; 385 patients received the fixed-dose combination (FDC) aclidinium-formoterol 400/12 $\mu \mathrm{g}, 381$ received the FDC aclidinium-formoterol 400/6 $\mu \mathrm{g}, 385$ received aclidinium $400 \mu \mathrm{g}$ alone, 384 received formoterol $12 \mu \mathrm{g}$ alone, and 194 received placebo, with all treatments twice daily. After 24 weeks, aclidinium-formoterol 400/12 $\mu \mathrm{g}$ and 400/6 $\mu \mathrm{g}$ achieved significant improvements from baseline in 1-hour postdose $\mathrm{FEV}_{1}$ versus aclidinium of $125 \mathrm{~mL}$ (95\% confidence interval [CI] 90-160, $P<0.001)$ and $69 \mathrm{~mL}(95 \% \mathrm{CI}$ 34-105, $P<0.001$ ), respectively, and trough $\mathrm{FEV}_{1}$ versus formoterol of $85 \mathrm{~mL}(95 \%$ CI 51-119, $P<0.001)$ and $53 \mathrm{~mL}(95 \%$ CI 19-87, $P<0.01)$, respectively. In addition, aclidinium-formoterol $400 / 12 \mu \mathrm{g}$ and $400 / 6 \mu \mathrm{g}$ led to significant improvement in Transition Dyspnea Index (TDI) score versus placebo $(P<0.001)$. Both aclidinium-formoterol twice-daily doses significantly improved bronchodilation versus monotherapy and dyspnea versus placebo. ${ }^{21}$

The AUGMENT COPD trial investigating aclidiniumformoterol for treatment of moderate-to-severe COPD included 1,692 patients with stable COPD, equally randomized to twice-daily treatment with the FDC aclidinium $400 \mu \mathrm{g}$-formoterol $12 \mu \mathrm{g}$, FDC aclidinium $400 \mu \mathrm{g}$-formoterol $6 \mu \mathrm{g}$, aclidinium $400 \mu \mathrm{g}$, formoterol $12 \mu \mathrm{g}$, or placebo administered by Genuair/Pressair in a 24-week double-blind study. The change from baseline to week 24 in 1-hour morning postdose $\mathrm{FEV}_{1}$ (FDCs versus aclidinium) and change from baseline to week 24 in morning predose (trough) $\mathrm{FEV}_{1}$ (FDCs versus formoterol) were the coprimary end points, while secondary end points were changes from baseline in SGRQ total score and improvement in TDI score at week 24. Significantly higher improvements from baseline in 1-hour postdose $\mathrm{FEV}_{1}$ were observed at study end in patients treated with aclidinium $400 \mu \mathrm{g}$-formoterol $12 \mu \mathrm{g}$ FDC or aclidinium $400 \mu \mathrm{g}$-formoterol $6 \mu \mathrm{g}$ FDC compared with aclidinium (108 $\mathrm{mL}$ and $87 \mathrm{~mL}$, respectively; $P<0.0001)$. Also, improvements in trough $\mathrm{FEV}_{1}$ were significantly greater in patients treated with aclidinium $400 \mu \mathrm{g}$-formoterol $12 \mu \mathrm{g}$ FDC versus formoterol; a numerical improvement of $26 \mathrm{~mL}$ in trough $\mathrm{FEV}_{1}$ over formoterol was observed with aclidinium $400 \mu \mathrm{g}$-formoterol $6 \mu \mathrm{g}$ FDC. As well, significant improvements in both SGRQ total and TDI focal scores were observed in the aclidinium $400 \mu \mathrm{g}$-formoterol $12 \mu \mathrm{g}$ FDC group at study end $(P<0.0001) .{ }^{22}$ Table 1 highlights the main findings from the two trials.

Bateman et al performed a pooled analysis of the data from the ACLIFORM and AUGMENT trials. The pooled intentto-treat population included 3,394 patients. Aclidiniumformoterol $400 / 12 \mu \mathrm{g}$ significantly improved TDI focal score versus placebo and both monotherapies at week 24 (all $P<0.05)$. Over 24 weeks, significant improvements in 


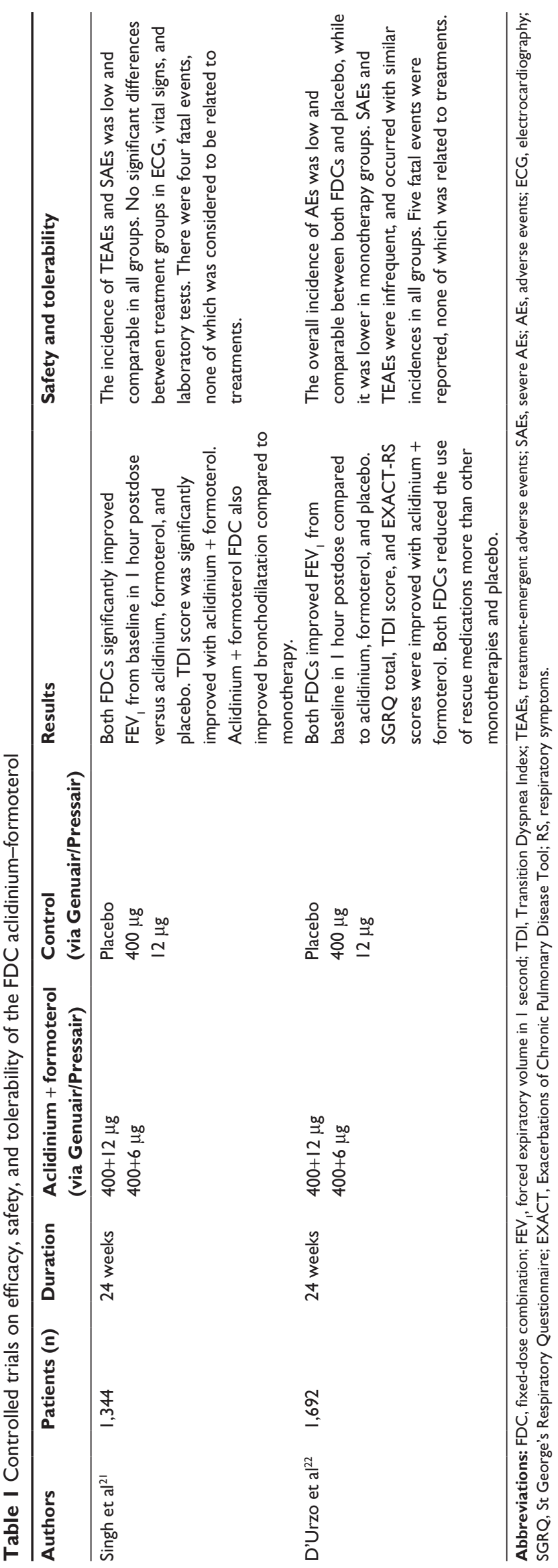

overall nighttime and early morning symptom severity and limitation of early morning activities were observed with aclidinium-formoterol $400 / 12 \mu \mathrm{g}$ versus placebo and both monotherapies (all $P<0.05$ ). Relief-medication use was reduced with aclidinium-formoterol $400 / 12 \mu \mathrm{g}$ versus placebo and aclidinium $(P<0.01)$. Aclidinium-formoterol $400 / 12 \mu \mathrm{g}$ significantly improved 24-hour symptom control compared with placebo, aclidinium, and formoterol in monotherapy patients with moderate-to-severe COPD. Furthermore, aclidinium-formoterol 400/12 $\mu \mathrm{g}$ reduced the frequency of exacerbations compared with placebo but not monotherapies. ${ }^{23}$

\section{Safety and tolerability}

As far as safety during treatment in COPD patients is concerned, in general formoterol at doses of $12 \mu \mathrm{g}$ and $24 \mu \mathrm{g}$ twice daily shows an incidence of adverse events similar to placebo. The most frequent drug-related adverse events are headache, tremor, dry mouth, muscle cramps, coughing, COPD exacerbations, dyspnea, and pruritus. Cardiovascular events and heart-rhythm disorders are uncommon, and the incidence of clinically relevant abnormal serum potassium and glucose is low. Also, similar kind and rate of adverse events were reported in studies comparing formoterol to salmeterol. In particular, tachycardia and tremor, known as class effects of $\beta_{2}$-agonists, were reported in a very low proportion of patients, with no evident dose relationship. ${ }^{24}$

In the Cochrane systematic review on aclidinium already cited, there was no difference in serious adverse events between aclidinium and placebo. Also, in studies comparing aclidinium to tiotropium, no significant differences in adverse events were found.$^{20} \mathrm{~A}$ review of all published trials concluded that aclidinium is well tolerated and safe for use as long-term COPD therapy. ${ }^{25}$ In the ACLIFORM-COPD trial, all treatments were well tolerated, with safety profiles of the aclidinium-formoterol combination similar to those of placebo and monotherapy with either drug. ${ }^{21}$ Also in the AUGMENT-COPD trial, all treatments were well tolerated, with safety profiles of the FDCs comparable to those of the monotherapies. ${ }^{22}$ The data on safety and tolerability in the two trials are summarized in Table 1.

\section{Patient-focused perspectives, including quality of life, satisfaction, and adherence}

Currently, GOLD (Global initiative for chronic Obstructive Lung Disease) recommends bronchodilators as a drugtreatment mainstay of COPD, limiting the use of ICS to 
patients with severe COPD or frequent exacerbations. ${ }^{2}$ This is mainly due to reports that ICS is associated with increased risk of pneumonia. Recently, Festic and Scanlon reviewed the pertinent literature, confirming that the association of use of ICS and incident pneumonia is substantial and concerned both randomized controlled trials and observational studies, though most studies had a significant risk of bias. The unadjusted higher risk of pneumonia is associated with longer duration of use, more potent ICS compounds, and higher doses. ${ }^{26}$ Therefore, in most COPD patients, treatment must be based on LABAs, LAMAs, and their combination. The place of LABA-LAMA combinations in stable patients with COPD was very recently systematically reviewed, and the data were pooled using a network, as well as a traditional direct comparison meta-analysis. A total of 23 trials with 27,172 patients were included in the analysis. From the patient perspective, the most important issue is that LABALAMA combinations were associated with a greater reduction in dyspnea, as indicated by improvement in TDI scores, and a greater improvement in quality of life, as assessed by the SGRQ score, than monotherapies. There were no statistically significant differences associated with LABA-LAMA combinations compared with monotherapies in safety outcomes or in severe exacerbations. ${ }^{27}$ No direct comparisons between aclidinium-formoterol and the other LABA-LAMA combinations, including indacaterol-glycopyrronium, olodaterol-tiotropium, and vilanterol-umeclidinium, are available yet. Also, specific studies on patient satisfaction and adherence are lacking and need to be performed. According to D'Urzo et al, aclidinium-formoterol has the characteristics to be implemented in clinical practice as part of a patient-focused approach to disease control. ${ }^{28}$ Actually, when the first LABAs with very long action were introduced, the expert opinion was that "the incorporation of once-daily dose administration is an important strategy to improve adherence and is a regimen preferred by most patients, which may also lead to enhancement of compliance". ${ }^{29}$ Still, twice-daily administration may also result in an advantage. In fact, the demonstration that aclidinium-formoterol can produce a significant synergistic interaction, expressed by the significant anticipation at 5 minutes postadministration of the bronchodilatory effect (as measured by $\mathrm{FEV}_{1}$ ) of the combination, compared with the effect of drugs administered alone, suggested a possible role also in the clinical setting. ${ }^{30}$ This was actually demonstrated by significant improvements in overall nighttime and early morning symptom severity and limitation of early morning activities in patients treated with the aclidinium-formoterol combination. ${ }^{23}$

\section{Patient profiles appropriate for the fixed combination of aclidinium- formoterol}

It is known that as for any other medical treatment, adherence to inhaled drugs for asthma and COPD is unsatisfactory, negatively affecting disease control and treatment costs. The rate of adherence to prescribed treatments for COPD is currently estimated at approximately $50 \% .{ }^{31}$ Factors causing nonadherence include patient knowledge/education, inhaler-device convenience and satisfaction, age, adverse effects, and medication costs. ${ }^{32}$ Generally, the number of doses to be administered each day is inversely correlated to adherence, ${ }^{33}$ and this issue was a major motivation to develop the once-daily LABAs and LAMAs. However, drug formulations satisfying the condition "one fits all" are very rare. The characteristics, attitudes, and preferences of individual subjects make it possible that some patients adhere more to twice-daily than to once-daily administration. As described earlier, patient perception of a fast onset of effect on respiratory symptoms, especially in the early morning, may positively influence adherence to two inhalations a day. In fact, lower adherence has been reported for medications that do not have an immediate effect on symptoms. ${ }^{33} \mathrm{~A}$ further aspect is satisfaction with inhaler devices, which is also positively correlated with improved adherence. A randomized, crossover study assessed patient preference, satisfaction, and critical inhaler-technique errors with the Genuair (to be used twice daily with aclidinium in a single formulation or in combination with formoterol) and the Breezhaler ${ }^{\circledR}$ (to be used once daily with glycopyrronium in a single formulation or in combination with indacaterol). The primary end point was the proportion of patients who preferred the Genuair versus the Breezhaler after 2 weeks, and other end points included overall satisfaction, correct use of the inhalers, and willingness to continue with each device. Of the 110 patients in the intent-to-treat population who indicated an inhaler preference, significantly more patients preferred the Genuair than the Breezhaler $(72.7 \%$ versus $27.3 \%, P<0.001)$. Mean overall satisfaction scores were also greater for the Genuair than for the Breezhaler (5.9 versus 5.3, respectively; $P<0.001$ ). The proportion of patients making critical inhaler-technique errors was low with both devices, with no significant difference between them. ${ }^{34}$ A recent survey investigated the usability of the Genuair device by elderly patients. After the first test, the device was considered "practical/handy" by $90 \%$ of patients and "easy to use" by $89 \%$, and the percentage of patients correctly using the device was $93 \%$ after a demonstration 
of the inhalation maneuver, with no differences between patients groups in terms of age, educational level, previous use of devices, or presence of arthritis/arthrosis. The authors concluded that the characteristics of the Genuair make it a valid choice in elderly patients, and enable them to cope better with the problems and difficulties that are common to this age-group. ${ }^{35}$ These observations show that the need for twicedaily administration may not be necessarily a disadvantage for the aclidinium-formoterol combination.

\section{Conclusion}

Treatment with the twice-daily aclidinium $400 \mu \mathrm{g}$-formoterol $12 \mu \mathrm{g}$ FDC provided in controlled trials rapid and sustained bronchodilation that was greater than either monotherapy. Clinically significant improvements in dyspnea and health status were evident compared with placebo. These data confer to the aclidinium-formoterol FDC a role as a new treatment option for patients with COPD. The need of twicedaily administration is an apparent weakness compared to the available once-daily LABA-LAMA combinations, but the immediately perceived benefit in reducing dyspnea due to the fast onset of action might prove useful in increasing adherence. ${ }^{36}$ This needs to be investigated by specific studies comparing once-daily and twice-daily LABA-LAMA combinations.

\section{Disclosure}

The authors report no conflicts of interest in this work.

\section{References}

1. Bellinger CR, Peters SP. Outpatients chronic obstructive pulmonary disease management: going for the GOLD. J Allergy Clin Immunol Pract. 2015;3(4):471-478.

2. GOLD (website on the Internet]. Available from: www.goldcopd.org. Accessed July 13, 2015.

3. Tattersfield AE. Clinical pharmacology of long-acting $\beta$-receptor agonists. Life Sci. 1993;52(26):2161-2169.

4. Barnes PJ. The pharmacological properties of tiotropium. Chest. 2000;117(2 Suppl):63S-66S.

5. Cazzola M, Page CP, Rogliani P, Matera MG. $\beta_{2}$-Agonist therapy in lung disease. Am J Respir Crit Care Med. 2013;187(7):690-696.

6. Ridolo E, Montagni M, Olivieri E, Riario-Sforza GG, Incorvaia C. Role of indacaterol and the newer very long-acting $\beta_{2}$-agonists in patients with stable COPD: a review. Int J Chron Obstruct Pulmon Dis. 2013;7:425-432.

7. Spina D. Current and novel bronchodilators in respiratory disease. Curr Opin Pulm Med. 2014;20(1):73-86.

8. Montuschi P, Ciabattoni G. Bronchodilating drugs for chronic obstructive pulmonary disease: current status and future trends. J Med Chem. 2015;58(10):4131-4164.

9. Faulds D, Hollingshead LM, Goa KL. Formoterol: a review of its pharmacological properties and therapeutic potential in reversible obstructive airways disease. Drugs. 1991;42(1):115-137.

10. Brogden RN, Faulds D. Salmeterol xinafoate: a review of its pharmacological properties and therapeutic potential in reversible obstructive airways disease. Drugs. 1991;42(5):895-912.
11. Derom E, Strandgården K, Schelfhout V, Borgström L, Pauwels R. Lung deposition and efficacy of inhaled formoterol in patients with moderate to severe COPD. Respir Med. 2007;101(9):1931-1941.

12. Casarosa P, Bouyssou T, Germeyer S, Schnapp A, Gantner F, Pieper M. Preclinical evaluation of long-acting muscarinic antagonists: comparison of tiotropium and investigational drugs. J Pharmacol Exp Ther. 2009;330(2):660-668.

13. Jansat JM, Lamarca R, Gil EG, Ferrer P. Safety and pharmacokinetics of single doses of aclidinium bromide, a novel long-acting, inhaled antimuscarinic, in healthy subjects. Int J Clin Pharmacol. 2009;47(7): 460-468.

14. Newman SP, Sutton DJ, Segarra R, Lamarca R, de Miquel G. Lung deposition of aclidinium bromide from Genuair, a multidose dry powder inhaler. Respiration. 2009;78(3):322-328.

15. Schelfhout VJ, Ferrer P, Jansat JM, et al. Activity of aclidinium bromide, a new long-acting muscarinic antagonist: a phase I study. $\mathrm{Br} J \mathrm{Clin}$ Pharmacol. 2010;69(5):458-464.

16. Moitra S, Bhome AB, Brashier BB. Aclidinium bromide/formoterol fixed-dose combination therapy for COPD: the evidence to date. Drug Des Devel Ther. 2015;9:1989-1999.

17. Welsh EJ, Cates CJ. Formoterol versus short-acting beta-agonists as relief medication for adults and children with asthma. Cochrane Database Syst Rev. 2010;(9):CD008418.

18. Global Initiative for Asthma [website on the Internet]. Available from: www.ginasthma.org. Accessed September 13, 2015.

19. Kew KM, Mavergames C, Walters JA. Long-acting $\beta_{2}$-agonists for chronic obstructive pulmonary disease. Cochrane Database Syst Rev. 2013;10:CD010177.

20. Ni H, Soe Z, Moe S. Aclidinium bromide for stable chronic obstructive pulmonary disease. Cochrane Database Syst Rev. 2014;9:CD010509.

21. Singh D, Jones PW, Bateman ED, et al. Efficacy and safety of aclidinium bromide/formoterol fumarate fixed-dose combinations compared with individual components and placebo in patients with COPD (ACLIFORM-COPD): a multicentre, randomised study. BMC Pulm Med. 2014;14:178.

22. D’Urzo AD, Rennard SI, Kerwin EM, Mergel V, Leselbaum AR, Caracta CF. Efficacy and safety of fixed-dose combinations of aclidinium bromide/formoterol fumarate: the 24-week, randomized, placebocontrolled AUGMENT COPD study. Respir Res. 2014;15:123.

23. Bateman ED, Chapman KR, Singh D, et al. Aclidinium bromide and formoterol fumarate as a fixed-dose combination in COPD: pooled analysis of symptoms and exacerbations from two six-month, multicentre, randomised studies (ACLIFORM and AUGMENT). Respir Res. 2015;16:92.

24. Steiropoulos P, Tzouvelekis A, Bouros D. Formoterol in the management of chronic obstructive pulmonary disease. Int J Chron Obstruct Pulmon Dis. 2008;3(2):205-215.

25. Zhong J, Roth M. Clinical potential of aclidinium bromide in chronic obstructive pulmonary disease. Ther Clin Risk Manag. 2014; 10:449-453.

26. Festic E, Scanlon PD. Incident pneumonia and mortality in patients with chronic obstructive pulmonary disease: a double effect of inhaled corticosteroids? Am J Respir Clin Care Med. 2015;191(2):141-148.

27. Oba Y, Sarva ST, Dias S. Efficacy and safety of long-acting $\beta$-agonist/ long-acting muscarinic antagonist combinations in COPD: a network meta-analysis. Thorax. 2016;71(1):15-25.

28. D’Urzo T, Donohue JF, Price D, Miravitlles M, Kerwin E. Dual bronchodilator therapy with aclidinium bromide/formoterol fumarate for chronic obstructive pulmonary disease. Expert Rev Respir Med. 2015;9(5):519-532.

29. Cazzola M, Matera MG. Novel long-acting bronchodilators for COPD and asthma. Br J Pharmacol. 2008;155(3):291-299.

30. Cazzola M, Calzetta L, Ora J, Puxeddu E, Rogliani P, Matera MG. Searching for the synergistic effect between aclidinium and formoterol: from bench to bedside. Respir Med. 2015;109(10):1305-1311.

31. Bender BG. Nonadherence in chronic obstructive pulmonary disease patients: what do we know and what should we do next? Curr Opin Pulm Med. 2014;20(2):132-137. 
32. Mäkelä MJ, Backer V, Hedegaard M, Larsson K. Adherence to inhaled therapies, health outcomes and costs in patients with asthma and COPD. Respir Med. 2013;107(10):1481-1490.

33. Toy EL, Beaulieu NU, McHale JM, et al. Treatment of COPD: relationships between daily dosing frequency, adherence, resource use, and costs. Respir Med. 2011;105(3):435-441.

34. Pascual S, Feimer J, De Soyza A, et al. Preference, satisfaction and critical errors with Genuair and Breezhaler inhalers in patients with COPD: a randomised, cross-over, multicentre study. NPJ Prim Care Respir Med. 2015;25:15018.
35. Blasi F, Canonica GW, Centanni S, et al. Genuair ${ }^{\sqrt{\circledR}}$ usability test: results of a national public survey of the elderly. COPD. Epub 2015 Dec 8.

36. Cazzola M, Beeh KM, Price D, Roche N. Assessing the clinical value of fast onset and sustained duration of action of long-acting bronchodilators for COPD. Pulm Pharmacol Ther. 2015;31:68-78.

\section{Publish your work in this journal}

Therapeutics and Clinical Risk Management is an international, peerreviewed journal of clinical therapeutics and risk management, focusing on concise rapid reporting of clinical studies in all therapeutic areas, outcomes, safety, and programs for the effective, safe, and sustained use of medicines. This journal is indexed on PubMed Central, CAS,
EMBase, Scopus and the Elsevier Bibliographic databases. The manuscript management system is completely online and includes a very quick and fair peer-review system, which is all easy to use. Visit http://www.dovepress.com/testimonials.php to read real quotes from published authors.

Submit your manuscript here: http://www.dovepress.com/therapeutics-and-clinical-risk-management-journal 